\title{
Remediation and development of a former military manufacturing and test site in Florida USA
}

\author{
R. L. Olsen ${ }^{1}$, A. B. Woods ${ }^{2} \&$ M. H. Edgar ${ }^{3}$ \\ ${ }^{I}$ CDM, Denver, Colorado USA \\ ${ }^{2}$ CDM, Orlando, Florida USA \\ ${ }^{3}$ CDM, Tallahassee, Florida USA
}

\begin{abstract}
Approaches for the redevelopment of contaminated properties vary depending upon many factors including type/extent of contamination, risks, regulatory authorities and compliance, remediation cost, the resources/desires of the owners, compliance with Federal SEC reporting and the value/demand for the property. Reducing the remediation cost and cleanup time of groundwater are common objectives at many sites because groundwater remediation is typically the most expensive, time consuming and difficult media to cleanup. Innovative techniques to reduce groundwater remediation timeframes at the Universal City Property Management site in Florida USA include the following:

- Use of horizontal wells to effectively capture and recover groundwater.

- Use of chemical oxidation to rapidly cleanup the contaminated groundwater.

- Use of horizontal wells to distribute chemical oxidants.

- Creation and use of open pit excavation to directly expose and aerate the resulting groundwater in situ and remove contamination.

Other approaches and elements that contributed to successful development of the site include:

- Flexible and dynamic remediation plans that respond to the owners need to sell or develop property to maintain a balanced cash flow.

- Effective and rapid remediation technologies (e.g., chemical oxidation) to facilitate property sale and development.

- Proactive coordination with regulatory agencies to build consensus and shorten review time of work plans and reports.

- Large area in a desirable location with great potential for development and revenue generation.
\end{abstract}

All of these approaches and attributes of the site contributed to the successful remediation and redevelopment.

Keywords: contaminated sites, cleanup, remediation, redevelopment. 


\section{Introduction}

The investigation, remediation, and development of contaminated sites in the USA occurs in many different ways using various approaches depending upon the type/extent of contamination, the environmental and human health risk, the application of appropriate regulatory limits, the remediation cost, the owners/developers intended future use of the site, and the property value and demand. The remediation and development of a formerly operated defense manufacturing and weapons systems test site in Orange County, Florida is discussed in the following sections. This site is not an official "Brownfields" site as designated by either Federal or State Agencies. However, the site is contaminated and is currently being remediated and developed into valuable commercial property using unique and innovative approaches. The site is very large in size and is located in highly desirable market area; therefore, the site has a great potential for extensive development and increase in value. For this site, the following items are discussed:

- Site background including types and sources of contamination

- Cleanup goals

- Remediation approaches

- Redevelopment status

\section{Universal City Property Management South Campus Project}

\subsection{Site background}

The project site is located in Orlando, Florida USA (see Figure 1). The site is approximately 2,000 acres in size and was formerly owned by a defense contractor. From 1958 to 1998, the defense contractor developed, manufactured, and tested weapon related equipment and systems. The site is currently surrounded by extensive development including the Orange County Convention Center, hotels and various tourist related attractions. In 1998, Universal City Property Management III LLC (UCPM) purchased the site from the previous owner and the site is now referred to as the UCPM South Campus. UCPM is a subsidiary of Stan Thomas Enterprises, a successful national commercial and industrial development company. Following UCPM's purchase, a comprehensive corrective action program was initiated to remediate soil and groundwater contamination attributed to past industrial use.

Nine main areas of the site have been identified for remediation (see Figure 1). Six of these areas are former landfills (Landfills $1-6$ ) and three of the areas are former test areas (Launch Test Area, Pershing/Waste Conservation Area, and Ordnance 2 Area). The aerial extent of the six landfills was approximately 25.5 acres. Landfill material requiring remediation included electroplating sludge, waste solvents and miscellaneous debris. Contaminated waste/debris/soil at the former landfills requiring excavation and disposal was up to 19 below land surface (bls). Besides contaminated waste, debris and soil, each 


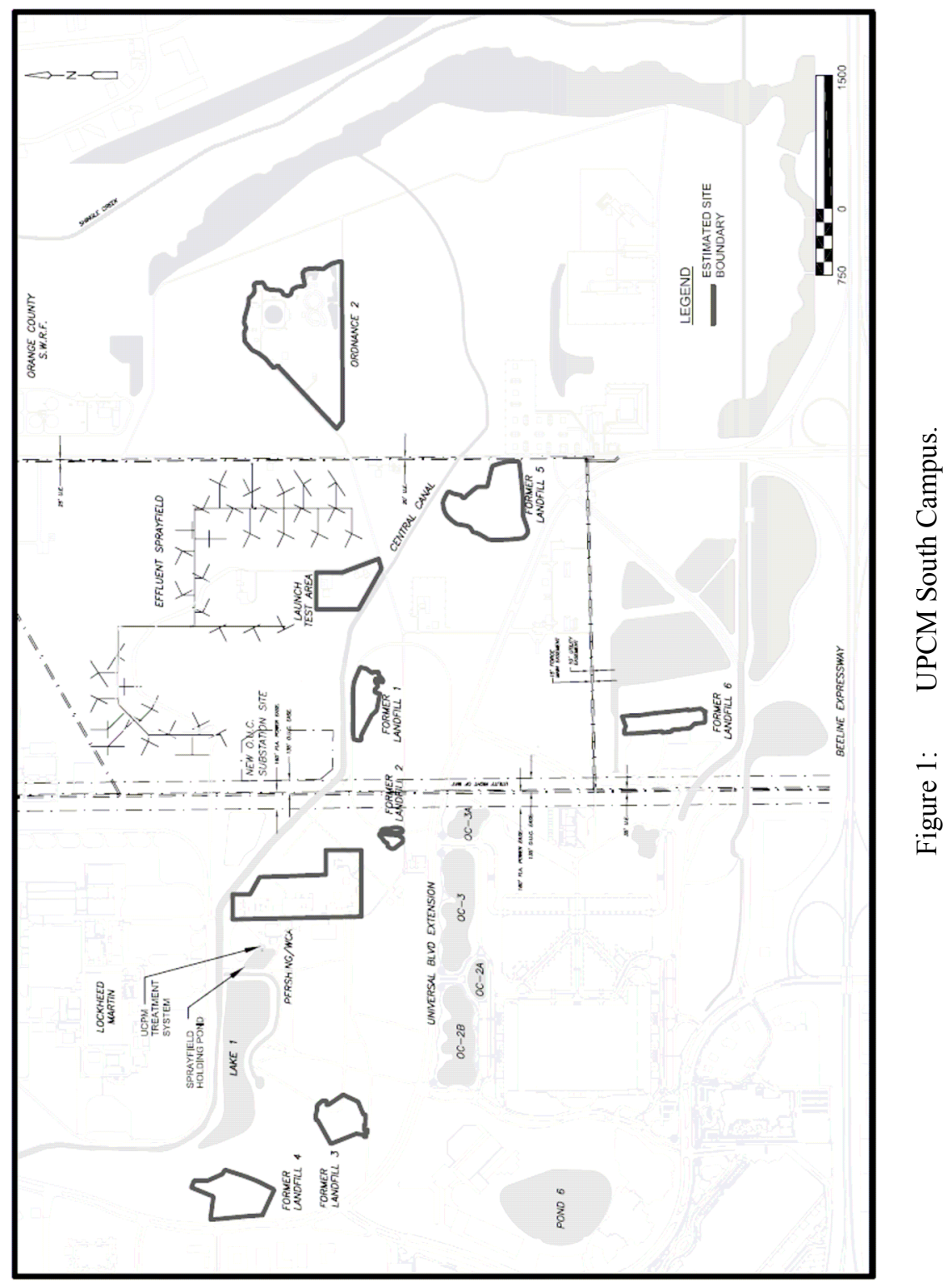


of the areas has associated groundwater contamination. Groundwater below the site exists in a series of interconnected and unconfined and semiconfined aquifer units including (top to bottom):

Table 1: $\quad$ Aquifer descriptions.

\begin{tabular}{|l|l|c|}
\hline Aquifer Name & Lithologic Description & Thickness (ft) \\
\hline Upper Surficial & $\begin{array}{l}\text { Poorly graded sand to silt; } \\
\text { clayey/silty sand; clean sand }\end{array}$ & $0-25$ \\
\hline Lower Surficial & Same as Upper & $20-50$ \\
\hline Upper Intermediate & Elastic silt with sand & $30-80$ \\
\hline Middle Intermediate & Limestone & $80-130$ \\
\hline Lower Intermediate & $\begin{array}{l}\text { Calcareous silt, limestone, carbonate } \\
\text { sands; sandy silt }\end{array}$ & $\begin{array}{l}\text { Calcareous clay; carbonate } \\
\text { sands/silts }\end{array}$ \\
\hline Upper Floridan & \multicolumn{1}{|l|}{$100-150$} \\
\hline
\end{tabular}

The top of the Floridan is typically at a depth of 120 to 140 feet below the ground surface. The major contaminants of concern in the groundwater are tetrachloroethene (PCE), trichloroethene (TCE), cis-1,2-dichloroethene (DCE), vinyl chloride (VC), toluene, and methylene chloride. Total volatile organics (TVOCs) range in concentration from 29 to $290,000 \mu \mathrm{g} / \mathrm{L}$. Table 2 summarizes the various sites, aquifer depth, plume size and highest TVOC's at the start of groundwater remediation activities.

Table 2: $\quad$ Plume characteristics.

\begin{tabular}{|c|c|c|c|c|}
\hline \multirow[t]{2}{*}{ Site } & \multicolumn{4}{|c|}{ Contaminant Plumes } \\
\hline & Aquifer & $\begin{array}{c}\text { Depth Interval } \\
\text { (ft bls) }\end{array}$ & $\begin{array}{c}\text { Plume } \\
\text { size (acres) }\end{array}$ & $\begin{array}{c}\text { Highest } \\
\text { TVOCs }(\mu \mathrm{g} / \mathrm{L})\end{array}$ \\
\hline \multirow[t]{4}{*}{ Landfill 1} & Upper Surficial & $0-25$ & 4.5 & 160,000 \\
\hline & Lower Surficial & $25-50$ & 4.3 & 290,000 \\
\hline & Intermediate" & $90-100$ & 2.3 & 20,000 \\
\hline & Floridan & $100-150$ & 2.7 & 74,000 \\
\hline \multirow[t]{2}{*}{ Landfill 3} & Surficial & $0-20$ & 9 & 46,000 \\
\hline & Lower Intermediate & $125-145$ & 5 & 2,100 \\
\hline \multirow[t]{3}{*}{ Landfill 4} & Surficial & $0-20$ & 5 & 7,300 \\
\hline & Upper Intermediate & $45-60$ & 8 & 40,000 \\
\hline & Lower Intermediate & $80-130$ & 0.5 & 2,500 \\
\hline \multirow[t]{4}{*}{ Landfill 5} & Surficial & $30-50$ & 19 & 18,000 \\
\hline & Upper Intermediate & $58-68$ & 10 & 740 \\
\hline & Lower Intermediate & $100-110$ & 2.7 & 410 \\
\hline & Floridan & $125+$ & 1.3 & 150 \\
\hline Landfill 6 & Surficial & $0-35$ & 3.0 & 850 \\
\hline \multirow[t]{2}{*}{ Launch test area } & Surficial & $0-25$ & 0.6 & 3,200 \\
\hline & Upper Intermediate & $30-60$ & 0.6 & 2,300 \\
\hline \multirow{3}{*}{$\begin{array}{l}\text { Pershing/Waste } \\
\text { conservation area }\end{array}$} & Upper Surficial & $0-10$ & 1 & 29 \\
\hline & Lower Surficial & $20-25$ & 11 & 12,000 \\
\hline & Upper Intermediate & $40-50$ & 25 & 5,800 \\
\hline
\end{tabular}


Over 110 acres of contaminated area and 3.4 billion gallons of contaminated groundwater existed at the site at the inception of groundwater remediation activities.

\subsection{Cleanup goals}

At the UCPM South Campus site, a unique combination of approaches to attaining remediation goals was adopted. For solid materials, the overall objective of the corrective action was to meet regulatory requirements as a RCRA Interim Measures Corrective Action. This required removal of RCRA hazardous wastes and proper disposal offsite at RCRA permitted landfills. Other nonhazardous debris and soil was also disposed offsite or reused on site as backfill. Initially for groundwater, the overall objective was to achieve hydraulic containment and management of the groundwater plumes. The ultimate goal was to reduce concentration of the contaminants of concern to levels at or below State of Florida Groundwater Cleanup Target Levels (GCTLs). GCTLs are equivalent to State of Florida maximum contaminant levels (MCLs) which are typically lower than USEPA's MCLs. For example, the Florida MCLs for TCE and PCE are $3 \mu \mathrm{g} / \mathrm{L}$ and for vinyl chloride, the MCL is $1 \mu \mathrm{g} / \mathrm{L}$ (vs. 5 and $2 \mu \mathrm{g} / \mathrm{L}$ for Federal MCLs). After maintaining concentrations at of below GCTLs for one year, a request for no further action (NFA) or equivalent would be requested from the Florida Department of Environmental Protection.

\subsection{Remediation}

Remediation alternatives were evaluated based on effectiveness in meeting cleanup goals, implementability, costs and time to achieve the cleanup goal. In addition, remediation is being performed to facilitate phased property development in accordance with economically driven build-out plans and demand for the property.

\subsubsection{Solid waste}

Numerous innovative assessment and construction methods helped to sustain the dynamic and fast-track schedule. Development goals required excavation of abandoned landfills containing varying amounts of hazardous and nonhazardous materials. To support work plan development for landfill excavation, the project team conducted test-pitting with an onsite geologist and survey team. Using the resulting data, the team constructed digital, three-dimensional terrain models that served as the basis of design for landfill excavation and waste volume calculations. Because of the potential for unexploded ordinance, a full-time ordnance expert was assigned during all landfill excavation activities. Materials were stockpiled and screened using on site analytical methods to rapidly determine chemical characteristics and select proper disposal or reuse. Table 3 summarizes the quantities excavated, stockpiles characterized, and materials disposed or reused from each of the six landfills.

Over a four year period 417,275 cubic yards of materials were excavated from the six former landfills. In total over 25.5 acres up to a depth of 19 feet were 





removed. During the time, 137 stockpiles of debris and 742 stockpiles of soil were characterized. In all 16,679 tons of RCRA F006 sludge were disposed off site. In addition, 19,804 tons of nonhazardous debris and 354,966 tons of nonhazardous soil were disposed off site. Approximately 32 percent of the excavated soil was used on site as backfill.

\subsubsection{Groundwater}

Preliminary assessment of the nature and extent of the plumes was performed using direct-push technology with an onsite mobile gas chromatography/mass spectrometry (GC/MS) laboratory. This allowed the project team to accurately investigate large plume areas at varying subsurface depths in a relatively short time period. Once the preliminary plume assessment was complete, monitoring wells were placed in strategic locations to confirm results.

Using existing and previously collected data, a centralized groundwater treatment facility capable of processing groundwater from all contaminated areas at the site was designed and constructed. The treatment system consists of two 500-gallon-per-minute tray air strippers (design capacity of 1,000 gpm), a one million gallon receiving pond and an effluent disposal sprayfield. The effluent disposal sprayfield distributes treated groundwater over 80 acres, reducing treated water disposal costs and recharging the regional aquifers.

Groundwater recovery systems were designed and installed at each contaminated site and then connected to the centralized groundwater treatment facility (see Figure 1). Detailed modeling of groundwater flow, contaminant transport, and particle tracking was conducted to facilitate groundwater recovery system design. The groundwater recovery systems consist of over 4,450 linear feet of horizontal recovery wells and 41 vertical recovery wells. One of the horizontal wells is currently deemed the largest in the world in terms of depth (50 feet) using a single one-pass trenching machine. To date over 60 million gallons of contaminated groundwater have been recovered, treated to drinking water standards, and then returned to the aquifer system. A summary of the groundwater remediation systems is provided in Table 4.

Current extraction and treatment flow is approximately 280 gallons per minute. Supplemental technologies are in the process of being implemented to accelerate groundwater remediation in conjunction with pump and treat. These include open pit aeration, enhanced bioremediation, chemical oxidation and natural attenuation. For example, the following supplemental technologies are being implemented to aggressively remediate the following aquifers and plumes:

Landfill 3:

- Surficial aquifer: open pit in situ aeration followed by chemical oxidation (potassium permanganate)

- Lower Intermediate: five deep injection and two recovery wells for permanganate injection and recovery 


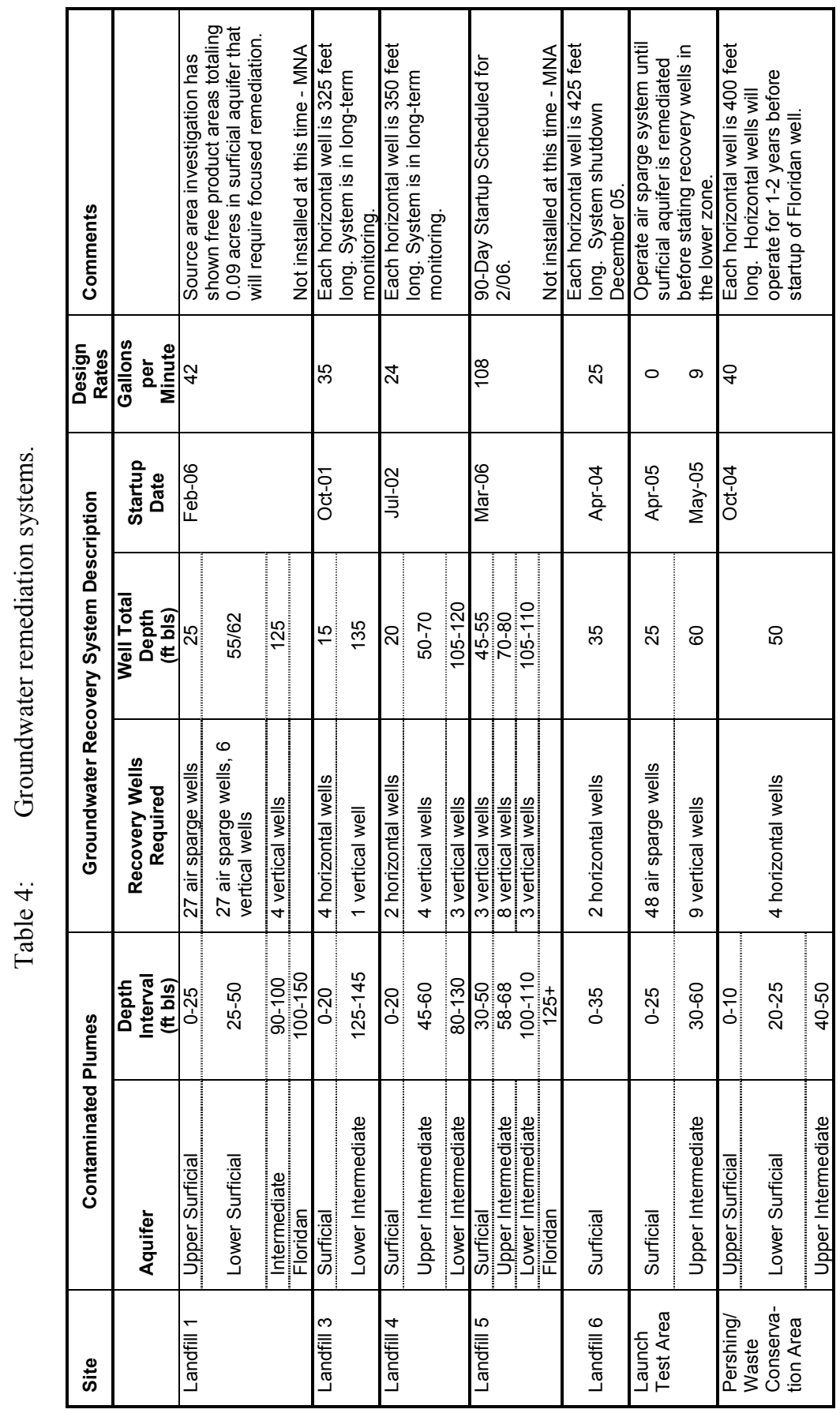


Landfill 4:

- Surficial: horizontal injection wells for permanganate distribution

- Upper Intermediate: 58 direct push wells for permanganate injection

As shown above, chemical oxidation is being combined with other effective techniques (pump and treat and open pit aeration) to accelerate remediation timeframes. Estimated cost to achieve no further action for groundwater at Landfills 3 and 4 using the above systems is approximately \$3.6 million. Remediation is anticipated to be completed in 3 years (including one year of post-remediation monitoring) at target cleanup levels.

To monitor the efficiency of the recovery and treatment systems, an extensive data collection network was installed. Data are collected to evaluate remedial progress for regulatory reporting and to allows UCPM and its consultants to refine and prioritize site development strategies.

\subsection{Redevelopment}

To date over $\$ 70$ million has been expended in total infrastructure costs at the site. Of this amount, approximately $\$ 35$ million is related to remediation of contaminated materials and groundwater. Current estimates are that over $\$ 250$ million will be expended for all infrastructure costs. The actual property investment value is estimated to be $\$ 2.5$ billion. To date, the following development has occurred:

Expansion of the Orange County Convention Center

Pulte Homes Vistas at Lake Cay (Resort Rentals)

Intrawest Village of Imagine (Resort Rentals)

Universal Boulevard Expansion

Canadian Court Expansion

Rosen's Shingle Creek Resort

UCF Hospitality School

\section{Conclusions}

Approaches to redevelopment of contaminated properties vary depending upon many factors including type/extent of contamination, environmental/human health risk, regulatory compliance, remediation costs, compliance with Federal SEC reporting, the resources/desires of the owners/developers and the value and demand for the property. Because of the high costs and long time associated with typical groundwater remediation, innovative techniques to reduce groundwater remediation timeframes were employed including:

- Use of horizontal wells to effectively capture and recover contaminated groundwater.

- Use of chemical oxidation to rapidly cleanup the contaminated groundwater to target cleanup levels.

- Use of horizontal wells to distribute chemical oxidants.

- Creation and use of open pits to directly aerate the exposed groundwater in situ and remove contamination. 
Reducing the remediation timeframe of groundwater is a common approach at many sites because groundwater remediation is typically the most expensive, time consuming and difficult media to ensure cleanup. In all cases, extensive evaluations and interaction with regulatory agencies were required to assure that the alternative approaches where protective of human health and the environment.

Other approaches and elements common that help result in successful development include:

- Integrated total site solutions allowing for cost saving approaches and synergism between individual areas of the site.

- Dynamic and real time investigations and to allow rapid characterization of contaminant levels and extent.

- On site and real time screening of excavated soils to allow rapid disposal and reuse decision processes.

- Flexible and dynamic remediation plans that could respond to the owners need to sell or develop property to maintain a balanced cash flow.

- Effective and rapid remediation technologies (e.g., chemical oxidation and open pit aeration) to facilitate property sale and development.

- Innovative and cost saving remediation techniques such as horizontal wells.

- Proactive coordination with regulatory agencies to build consensus and shorten review time of work plans, reports, etc.

- Large area in desirable location with great potential for development and revenue generation.

- Interim cleanup and development of selected areas while the remaining portions of the site were being investigated and remediated, which generated cash flow to allow site infrastructure construction and remediation measures implementation.

All of these approaches and attributes of the sites contributed to the ongoing successful remediation and redevelopment. 